\title{
PCR-RFLP detection of point mutations A2143G and A2142G in 235 rRNA gene conferring resistance to clarithromycin in Helicobacter pylori strains*
}

\author{
Karolina Klesiewicz¹, Paweł Nowak ${ }^{\circledR}$, Elżbieta Karczewska¹, Iwona Skiba, Izabela Wojtas- \\ Bonior ${ }^{1}$, Edward Sito ${ }^{2}$ and Alicja Budak ${ }^{1}$
}

'Department of Pharmaceutical Microbiology, Jagiellonian University Medical College, Kraków, Poland; ${ }^{2}$ Falck Medycyna Outpatient Clinic of Gastroenterology, Kraków, Poland

\begin{abstract}
Background. The occurrence of clarithromycin resistance among Helicobacter pylori strains is a major cause of the treatment failure. Resistance to this drug is conferred by point mutations in $23 \mathrm{~S}$ rRNA gene and the most prevalent mutations are A2143G and A2142G. The aim of the study was to evaluate the occurrence of A2143G and $\mathrm{A} 2142 \mathrm{G}$ mutations in a group of $H$. pylori strains resistant to clarithromycin. Materials and Methods. The study included 21 clarithromycin-resistant $H$. pylori strains collected between 2006 and 2009 in southern Poland. Resistance to clarithromycin was quantitatively tested with the E-test to determine the minimal inhibitory concentration (MIC value). The point mutations of $H$. pylori isolates were detected by PCR followed by RFLP analysis. Results. The MIC values for clarithromycin for the analyzed strains ranged from $1.5 \mathrm{mg} / \mathrm{L}$ to $64 \mathrm{mg} / \mathrm{L}$. Nine H. pylori strains exhibited A2143G mutation and A2142G mutation was found in 9 isolates as well. The results of RFLP analysis of 3 clarithromycin-resistant strains were negative for both mutations. The average MIC values for A2143G and A2142G mutants were 6 and $30 \mathrm{mg} / \mathrm{L}$, respectively. Conclusions. Frequencies of A2143G and A2142G mutations were the same in all isolates tested. Strains with A2143G mutation exhibited lower MIC values than A2142G mutants. Application of PCR-RFLP method for detection of clarithromycin resistance allows for better and more efficient management of $H$. pylori infections.
\end{abstract}

Key words: Helicobacter pylori, clarithromycin resistance, PCR-RFLP, point mutations

Received: 30 October, 2013; revised: 18 March, 2014; accepted: 22 May, 2014; available on-line: 13 June, 2014

\section{INTRODUCTION}

Helicobacter pylori is a Gram-negative, spiral-shaped, microaerophilic bacterium which colonizes gastric mucosa of $50 \%$ of the human population worldwide. Moreover, H. pylori is a major cause of upper gastrointestinal tract diseases such as: dyspepsia, type B gastritis, gastric ulcer disease, and duodenal ulcer disease (Perez-Perez et al., 2004; Malfertheiner et al., 2012; den Hollander, 2013). $H$. pylori is also considered as a class I carcinogen, involved in the formation of gastric cancer and mucosa-associated lymphoid tissue (MALT) lymphoma (IARC,
1994; Ando et al., 2006; Konturek et al., 2009; Gisbert et al., 2011; Figueiredo et al., 2013).

Current recommendations for the management of H. pylori infection were elaborated by the European Helicobacter Study Group (EHSG) and presented in Maastricht IV/Florence Consensus Report in 2012. According to these guidelines, an effective treatment requires combined therapy, and it is important to take into consideration $H$. pylori resistance to clarithromycin on the area the patient is coming from (areas of low $(<20 \%)$ and high (>20\%) prevalence) (Malfertheiner et al., 2012).

Clarithromycin is one of the most common components of $H$. pylori infection treatment schemes. It is included in the standard triple therapies, as well as in non-bismuth quadruple therapies (either sequential or concomitant) (Malfertheiner et al., 2012). Moreover, clarithromycin is found to be one of the most effective antimicrobial agents used in the treatment of $H$. pylori infection (de Francesco et al., 2006). However, it should be remembered, that the development of clarithromycin resistance is a major cause of $H$. pylori treatment failure (Mégraud, 2004; Giorgio et al., 2013).

Clarithromycin is a semisynthetic 14-membered macrolide antibiotic with bacteriostatic activity against broad-spectrum of microorganisms including $H$. pylori. Due to this fact, this drug is widely used in the treatment of respiratory tract and skin diseases, as well as upper-gastrointestinal tract diseases caused by $H$. pylori. While clarithromycin is relatively stable in gastric juice, the use of an acid-suppressive drug (e.g. proton pumps inhibitor (PPI)) enhances the therapeutic effect of this antimicrobial agent. Moreover, therapeutic activity of clarithromycin is also related to its delivery to the gastric mucosa (Erah et al., 1997; Dzierżanowska, 2009; Fuki et al., 2011).

Antibacterial activity of clarithromycin is related to inhibition of bacterial protein synthesis by reversible binding to the $50 \mathrm{~S}$ ribosomal subunits. The target site of clarithromycin is the peptidyl transferase loop of $\mathrm{V}$ domain of $23 \mathrm{~S}$ ribosomal RNA molecule. Because of this binding, the translocation of aminoacyl transfer-RNA is

e-mail: p.nowak@uj.edu.pl

*The preliminary report on the same subject was presented at MIKROBIOT 2013 Workshop, Łódź, Poland

Abbreviations: EHSG, European Helicobacter Study Group; EUCAST, European Committee on Antimicrobial Susceptibility Testing; MALT, mucosa-associated lymphoid tissue lymphoma; MIC, minimal inhibitory concentration; PCR, Polymerase Chain Reaction; RFLP, Restriction Fragments Length Polymorphism 
effectively blocked resulting in the inhibition of protein synthesis (Dzierżanowska, 2009; Gerrits et al., 2006).

Resistance to clarithromycin is associated with the target site modifications and efflux pumps. Target site modifications are mediated by two mechanisms: 1) point mutations in the peptidyl transferase-encoding region of $\mathrm{V}$ domain of $23 \mathrm{~S} \mathrm{rRNA}$ gene and 2) post-transcriptional methylation of 23S rRNA region (Gerrits et al., 2006; Mégraud \& Lehours, 2007; Hirata et al., 2010).

The mechanism of clarithromycin resistance in $H$. $p y$ lori is mainly associated with the following point mutations in 23S rRNA gene:

1) $A 2143 G$ (previously described as $A 2144 G$ ) occurring in $69.8 \%$ of strains;

2) A2142G (previously described as A2143G) occurring in $11.7 \%$ of isolates;

3) A2142C reported in 2.6\% strains (Taylor et al., 1997; Mégraud, 2004; Gerrits et al., 2006; Karczewska et al., 2009; Francavilla et al., 2010).

Moreover, other mutations such as A2115G, G2141A, C2147G, T2190C, C2195T, A2223G, and C2694A have been identified among $H$. pylori strains resistant to clarithromycin, although their role in the mechanism of resistance remains unclear (Hao et al., 2004; Mégraud, 2004; Gerrits et al., 2006; Agudo et al., 2010).

One of the major factors contributing to clarithromycin resistance of $H$. pylori strains is high outpatient consumption of clarithromycin, especially in the treatment of respiratory tract diseases (Mégraud, 2004; Mégraud et al., 2013). Mean rate of $H$. pylori clarithromycin resistance in Europe amounted to $17.5 \%$. However, diversity between the regions could be observed: $7.7 \%$ in the Northern European countries, $18.7 \%$ in Western/Central Europe, and 21.5\% in Southern Europe (Mégraud et al., 2013). In Poland, according to our recent studies conducted in the years 2006-2008 and 2009-2011, the rate of H. pylo$r i$ clarithromycin resistance among adults was 34\% and $22 \%$, respectively (Karczewska et al., 2011; Karczewska et al., 2012). Therefore, according to the Maastricht IV/ Florence Consensus Report, southern Poland should be classified as a high clarithromycin resistance region (Malfertheiner et al., 2012).

Over the years, numerous methods have been developed to detect the resistance of $H$. pylori to clarithromycin. These methods can be divided into two groups: phenotypic and genotypic. Antibiotic susceptibility testing of $H$. pylori is routinely performed with the use of phenotypic methods. This assay, preceded by culturing of bacteria, includes both agar dilution technique and the use of strips impregnated with antimicrobial agent gradient (e.g. E-test, bioMérieux, France). In addition, these methods are labor-intensive and time-consuming; full testing takes up to two weeks. Unfortunately, as estimated, culture based methods fail in about $10 \%$ of cases due to contamination of biopsy specimens or growth difficulties (Gerrits et al., 2006). While culture-based phenotypic methods are time consuming, nucleic acid-based techniques could offer a faster and more accurate alternative. Molecular detection of clarithromycin resistance among $H$. pylori strains is mostly based on analysis of the unique point mutations in $23 \mathrm{~S}$ rRNA gene. These techniques make it possible to determine the resistance profiles of $H$. pylori strains from cultured isolates as well as directly from biopsies or stool samples (Oleastro et al., 2003; Booka et al., 2005; Rimbara et al., 2005; Ho et al., 2010). The most important methods used to detect mutations are PCR followed by RFLP (restriction fragment length polymorphism) and Real-Time PCR (using SYBRGreen and/or labeled probes), although other methods are applied as well: PCR-DNA enzyme immunoassay, mismatched PCR, hybridization and sequencing techniques (Chisholm et al., 2001; Mégraud, 2004; Schabereiter-Gurtner et al., 2004; Gerrits et al., 2006; Agudo et al., 2010). While molecular methods are more reliable and less time-consuming than the phenotypic ones, they are still not routinely used for detection of clarithromycin-resistant H. pylori strains in Poland. PCR-RFLP is performed to detect the most common point mutations in 23S rRNA gene, such as: A2143G, A2142G and A2142C (Occhialini et al., 1997; Ménard et al., 2002; Agudo et al., 2011). This method is based on the presence or absence of the sites recognized by restriction enzymes within the amplified DNA fragment (Gerrits et al., 2006; Mégraud \& Lehours, 2007).

The aim of the present study was to detect the two most prevalent point mutations: A2143G and A2142G in 23S rRNA gene associated with clarithromycin resistance of $H$. pylori strains with the use of PCR-RFLP technique.

\section{MATERIALS AND METHODS}

Gastric biopsy specimens and $\boldsymbol{H}$. pylori strains. Twenty-one clarithromycin-resistant $H$. pylori clinical strains subjected to the study were obtained from gastric biopsy specimens of patients with upper-gastrointestinal tract diseases, from Falck Medycyna Outpatient Clinic of Gastroenterology (Krakow, Poland) between 2006 and 2009.

H. pylori strains were isolated according to the following procedure:

- homogeneous tissue was spread onto both: non selective (Schaedler agar with 5\% sheep blood, bioMérieux, France) and selective (Schaedler agar with 5\% sheep blood and selective supplement Dent, Oxoid, UK) media and incubated up to 10 days under microaerophilic conditions at $37^{\circ} \mathrm{C}$;

- identification of $H$. pylori strains was based on: microscopic appearance of colonies, negative Gram staining and positive biochemical tests for urease, catalase and oxidase;

- isolated strains were frozen and stored at $-80^{\circ} \mathrm{C}$ for further analysis in Scheadler anaerobe broth (Oxoid, UK) supplemented with fetal bovine serum (Sigma-Aldrich, Germany) and glycerol (POCH, Poland).

The design of the study was approved by the Bioethical Commission of the Jagiellonian University and each patient signed an informed consent before participation in the study.

Determination of the clarithromycin resistance with the use of phenotypic method (E-test). Clarithromycin resistance was determined quantitatively, as the minimal inhibitory concentration (MIC value), with the use of strips impregnated with the antibiotic gradient (E-test, bioMérieux, France). Colonies were taken from the pure $H$. pylori cultures and suspended in sterile saline ( $\mathrm{NaCl} 0.85 \%$ Medium, bioMérieux, France) on an equivalent of $3.0 \mathrm{McF}$ arland units. The inoculum was spread onto Schaedler agar medium with 5\% sheep blood (bioMérieux, France) with sterile cotton swabs. Etest strips with clarithromycin gradient were separately placed on inoculated plates according to the manufacturer recommendations (E-test technical manual, bioMérieux, France). The inoculated plates with strips were incubated under microaerophilic conditions for 72 hours at $37^{\circ} \mathrm{C}$. 
Table 1. Conditions of digestion with restriction enzymes (enzymes, thermal profiles and products size).

\begin{tabular}{lllll}
\hline Mutation & Enzyme & Thermal profile & Products size & References \\
\hline A2143G & Eco31l (Bsal) & $37^{\circ} \mathrm{C}(30 \mathrm{~min}), 65^{\circ} \mathrm{C}(5 \mathrm{~min})$ & $304 \mathrm{bp}$ and $101 \mathrm{bp}$ & Agudo et al., 2011 \\
\hline A2142G & $\mathrm{Bbsl}$ & $37^{\circ} \mathrm{C}(24 \mathrm{~h})$ & $332 \mathrm{bp}$ and $93 \mathrm{bp}$ & Occhialini et al., 1997 \\
\hline
\end{tabular}

H. pylori strains were classified as resistant when the clarithromycin MIC values exceeded $0.5 \mathrm{mg} / \mathrm{L}$ (according to the European Committee on Antimicrobial Susceptibility Testing (EUCAST) breakpoint tables for interpretation of MICs and zone diameters).

Bacterial genomic DNA extraction. DNA was extracted from pure 72-hour $H$. pylori cultures. Colonies were suspended in $1 \mathrm{ml}$ of sterile saline $(\mathrm{NaCl}$ $0.85 \%$ Medium, bioMérieux, France) and centrifuged (12000 rpm/3 min). Total bacterial genomic DNA was isolated with the use of Sherlock AX isolation kit (A\&A Biotechnology, Poland), according to the manufacturer's recommendations. The eluted DNA was stored at $-20^{\circ} \mathrm{C}$ until use.

Determination of the clarithromycin resistance with the use of genotypic method (PCR-RFLP). Detection of the most common point mutations (A2143G, A2142G) conferring resistance to clarithromycin in H. pylori strains was performed by PCR followed by RFLP analysis.

PCR assay was conducted using primers and thermal profiles described by Agudo (Agudo et al., 2011) (K1 sense: CCA CAG CGA TGT GGT CTC AG and K2 - antisense: CTC CAT AAG AGC CAA AGC CC). The reaction mixture of the final volume $25 \mu \mathrm{l}$ contained: $2 \mu \mathrm{l}$ of genomic DNA, $2 \mu \mathrm{l}$ of each primer, $5 \mu \mathrm{l}$ of GoTaq ${ }^{\circledR}$ Flexi Buffer, $1.5 \mu \mathrm{l}$ of $\mathrm{MgCl}_{2}(25 \mathrm{mM}), 0.5 \mu \mathrm{l}$ of PCR Nucleotide Mix (10 mM each), $0.125 \mu \mathrm{l}$ of GoTaq ${ }^{\circledR}$ DNA Polymerase $(5 \mathrm{u} / \mu \mathrm{l})$ and Nuclease-Free Water (Promega, USA).

Amplicon of 425-base-pairs was visualized after electrophoresis in $2 \%$ agarose gel stained with ethidium bromide.

The RFLP assay was carried out with Eco31I (BsaI) enzyme (Thermo Scientific, USA) in order to detect A2143G mutation, while BbsI enzyme (New England Biolabs, USA) was used to detect A2142G mutation. Digestion thermal profiles are shown in Table 1. The analysis was carried out against ATCC 700684 reference clarithromycin-resistant $H$. pylori strain possessing A2143G mutation.

\section{RESULTS AND DISCUSSION}

H. pylori resistance to clarithromycin is predominantly related to the point mutations in the peptidyl transferaseencoding region of $\mathrm{V}$ domain of $23 \mathrm{~S}$ rRNA gene. The most prevalent point mutations responsible for this process are A2143G, A2142G, and A2142C (Mégraud, 2004).

\section{Prevalence of point mutations}

PCR-RFLP analysis was performed on $21 \mathrm{H}$. pylori strains resistant to clarithromycin in order to detect the two most common point mutations: $A 2143 \mathrm{G}$ and A2142G in 23S rRNA gene. Figure 1 shows the results of restriction fragment length polymorphism analysis of 23S rRNA amplicons (425 bp) with Eco31I (BsaI) and BbsI enzymes.

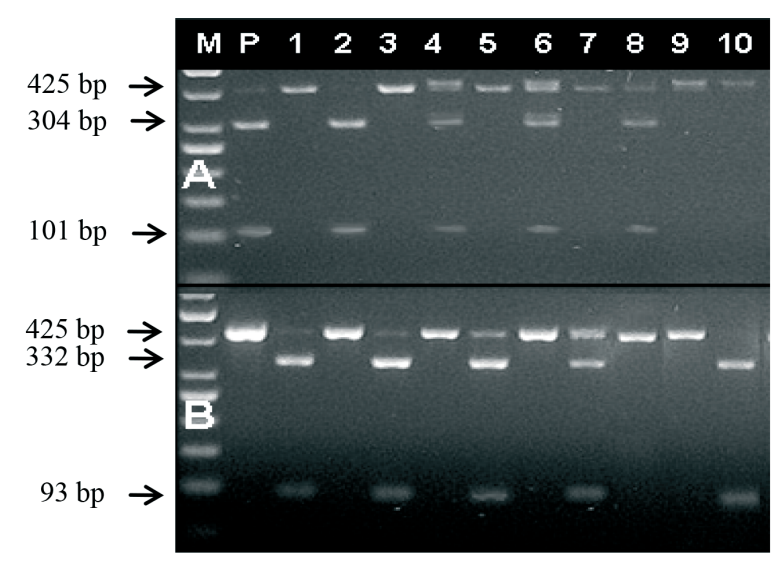

Figure 1. RFLP analysis of $23 \mathrm{~S}$ rRNA amplicons (425 bp) digested with:

(Part A) Eco31I (Bsal) enzyme (digestion products of 304 and 101 bp - for A2143G mutants); (Part B) Bbsl enzyme (digestion products of 332 and $93 \mathrm{bp}-$ for A2142G mutants); Lines 1-10: clinical H. pylori isolates; Lines 1, 3, 5, 7, 10: A2142G H. pylori mutants; Lines 2, 4, 6, 8: A2143G H. pylori mutants; Line 9: clarithromycinresistant isolate with negative results for both assayed mutations; $\mathrm{P}-\mathrm{H}$. pylori ATCC 700684; M - Molecular Weight Marker (50 bp O'Gene Ruler, Thermo Scientific, USA).

Among 21 clarithromycin-resistant $H$. pylori strains included in our study, more than $90 \%$ of isolates carried A2143G (9; 42.9\%) or A2142G (9; 42.9\%) mutation. Therefore, our research confirms the reports of several authors that the predominant mutations responsible for clarithromycin resistance in $H$. pylori are A2143G and A2142G (Occhialini et al., 1997; Mégraud, 2004).

Prevalence of the particular point mutations varies across geographical areas. Versalovic et al. (1997) showed that the majority of $H$. pylori isolates from American patients carried A2143G (previously A2144G) mutation $(52.5 \%)$, whereas $39 \%$ of strains contained A2142G (previously A2143G) mutation. Also, among French patients, A2143G mutation was predominant in clarithromycinresistant strains - 90\% of A2143G vs. $10 \%$ of A2142G mutants (Raymond et al., 2007). Alvarez et al. (2009) confirmed that A2143G mutation was more frequent among patients from Colombia and could be found in $75 \%$ of H. pylori clarithromycin-resistant strains. According to the review conducted by Mégraud (Mégraud, 2004), the most common mutation was A2143G that occurred in about $69.8 \%$ of strains resistant to clarithromycin, but its prevalence varied from $52.7 \%$ in Germany up to $95.6 \%$ in Hong Kong. In Poland, $72 \%$ of the clarithromycinresistant strains isolated from children, were reported to carry A2143G mutation (Rożynek et al., 2002). The average prevalence of $\mathrm{A} 2142 \mathrm{G}$ mutation amounted to $11.7 \%$ and ranged from $5 \%$ of the resistant strains in Iran to $66.6 \%$ in Japan (Mégraud, 2004). Twenty per cent of $H$. pylori strains isolated from Polish patients were A2142G mutants (Rożynek et al., 2002). While most researchers concluded that A2143G mutation was more common than A2142G one (Versalovic et al., 1997; Mé- 
graud, 2004; Raymond et al., 2007; Agudo et al., 2011), we observed equal prevalence of both mutations in all analyzed strains. The discrepancies between our results and the results of other authors may have arisen from either geographical origin of the isolates or limited number of tested strains.

Our PCR-RFLP analysis revealed also the occurrence of three clarithromycin-resistant strains $(14.2 \%)$ without any of the assayed mutations. In these isolates, resistance to clarithromycin might be associated with other less common mutations or with the efflux mechanism. Therefore, further analysis are required. In future, these mechanisms could be detected using PCR-RFLP or Real-Time PCR (Menard et al., 2002; Mégraud \& Lehours, 2007).

\section{Association between the type of mutation and the level of clarithromycin resistance}

According to some authors, different types of mutations are associated with different MIC values (Raymond et al., 2007). Correlation between the type of mutation and the MIC value for 21 analyzed $H$. pylori isolates is presented in Table 2. In our study, a MIC value exceeding $32 \mathrm{mg} / \mathrm{L}$ was defined as high-level resistance to clarithromycin (Versalovic et al., 1997).

In our study, all of A2143G H. pylori mutants demonstrated low MIC values to clarithromycin (MICs $\leq 32 \mathrm{mg} / \mathrm{L}$ ), while in A2142G mutants we observed strains of both phenotypes; with high- or low-level of resistance. However, the results of our study showed that the strains with A2143G mutation had lower average MIC values than strains with A2142G mutation (6 $\mathrm{mg} / \mathrm{L}$ and $30 \mathrm{mg} / \mathrm{L}$, respectively). These results are consistent with those reported by other researchers who concluded that A2143G point mutation was correlated with lower clarithromycin MIC values than A2142G one (Stone et al., 1997; Versalovic et al., 1997; de Francesco et al., 2006; Gerrits et al., 2006; Raymond et al., 2007; Alvarez et al., 2009).

To conclude, PCR-RFLP method performed from pure $H$. pylori culture reduces the time of determination of clarithromycin resistance by about 4 days comparing to phenotypic methods of susceptibility testing. Faster detection of clarithromycin resistance enables selection of treatment regimen without clarithromycin according to EHSG recommendations, particularly in the regions of high clarithromycin resistance, such as Poland.

\section{Acknowledgements}

We gratefully acknowledge financial support received from the Polish Government as targeted grant for young researchers and Ph.D. students under 35 (K/ DSC/000777). Our work was supported in part by this grant.

Table 2. Correlation between clarithromycin MIC values [mg/L] and the type of mutation in $23 \mathrm{~S}$ rRNA gene of $H$. pylori strains resistant to clarithromycin.

\begin{tabular}{llll}
\hline \multirow{3}{*}{ Mutation } & \multicolumn{2}{l}{ No. (\%) of strains } & \multicolumn{2}{l}{$\begin{array}{l}\text { MIC } \leq 32 \mathrm{mg} / \mathrm{L} \\
\mathrm{n}=18\end{array}$} & $\begin{array}{l}\text { MIC }>32 \mathrm{mg} / \mathrm{L} \\
\mathrm{n}=3\end{array}$ & $\begin{array}{l}\text { Total } \\
\mathrm{n}=21\end{array}$ \\
\hline A2142G & $6(33.3)$ & $3(100)$ & $9(42.9)$ \\
\hdashline A2143G & $9(50)$ & $0(0)$ & $9(42.9)$ \\
\hline Undetermined & $3(16.7)$ & $0(0)$ & $3(14.2)$ \\
\hline
\end{tabular}

\section{REFERENCES}

Agudo S, Alarcón T, Urruzuno P, Martínez MJ, López-Brea M (2010) Detection of Helicobacter pylori and clarithromycin resistance in gastric biopsies of pediatric patients by using a commercially available real-time polymerase chain reaction after NucliSens semiautomated DNA extraction. Diagn Microbiol Infect Dis 67: 213-219.

Agudo S, Pérez-Pérez G, Alarcón T, López-Brea M (2011) Rapid detection of clarithromycin resistant Helicobacter pylori strains in Spanish patients by polymerase chain reaction-restriction fragment length polymorphism. Rev Esp Quimioter 24: 32-36.

Alvarez A, Moncayo JI, Santacruz JJ, Santacoloma M, Corredor LF, Reinosa E (2009) Antimicrobial susceptibility and mutations involved in clarithromycin resistance in Helicobacter pylori isolates from patients in the western central region of Colombia. Antimicrob Agents Chemother 53: 4022-4024.

Ando T, Goto Y, Maeda O, Watanabe O, Ishiguro K, Goto H (2006) Causal role of Helicobacter pylori infection in gastric cancer. World $J$ Gastroenterol 12: 181-186.

Booka M, Okuda M, Shin K, Miyashiro E, Hayashi H, Yamauchi K, Tamura Y, Yoshikawa N (2005) Polymerase chain reaction - restriction fragment length polymorphism analysis of clarithromycin-resistant Helicobacter pylori infection in children using stool sample. Helicobacter 10: 205-213.

Chisholm SA, Owen RJ, Teare EL, Saverymuttu S (2001) PCR-based diagnosis of Helicobacter pylori infection and real-time determination of clarithromycin resistance directly from human gastric biopsy samples. J Clin Microbiol 39: 1217-1220.

Dzierżanowska D (2009) Makrolidy i ketolidy. In: Antybiotykoterapia praktyczna, pp 133-140, $\alpha$-medica press, Bielsko-Biała (in Polish).

Erah PO, Goddard AF, Barrett DA, Shaw PN, Spiller RC (1997) The stability of amoxycillin, clarithromycin and metronidazole in gastric juice: relevance to the treatment of Helicobacter pylori infection. J $A n$ timicrob Chemother 39: 5-12.

European Committee on Antimicrobial Susceptibility Testing (2013) Breakpoint tables for interpretation of MICs and zone diameters. Version 3.1, valid from 2013-02-11: http://www.eucast.org/fileadmin/src/media/PDFs/EUCAST_files/Breakpoint_tables/Breakp.

Figueiredo C, Garcia-Gonzalez MA, Machado JC (2013) Molecular pathogenesis of gastric cancer. Helicobacter 18: 28-33.

Francavilla R, Lionetti E, Castellaneta S, Margiotta M, Piscitelli D, Lorenzo L, Cavallo L, Ierardi E (2010) Clarithromycin-resistant genotypes and eradication of Helicobacter pylori. I Pediatr 157: 228-232.

de Francesco V, Margiotta M, Zullo A, Hassan C, Valle ND, Burattini O, Cea U, Stoppino G, Amoruso A, Stella F, Morini S, Panella C, Ierardi E (2006) Primary clarithromycin resistance in Italy assessed on Helicobacter pylori DNA sequences by TaqMan real-time polymerase chain reaction. Aliment Pharmacol Ther 23: 429-435.

Fujiki S, Iwao Y, Kobayashi M, Miyagishima A, Itai S (2011) Stabilization mechanism of clarithromycin tablets under gastric $\mathrm{pH}$ conditions Chem Pharm Bull (Tokyo) 59: 553-558.

Gerrits MM, van Vliet AH, Kuipers EJ, Kusters JG (2006) Helicobacter pylori and antimicrobial resistance: molecular mechanisms and clinical implications. Lancet Infect Dis. 6: 699-709.

Giorgio F, Principi M, De Francesco V, Zullo A, Losurdo G, Di Leo A, Ierardi E (2013) Primary clarithromycin resistance to Helicobacter pylori: Is this the main reason for triple therapy failure? World J Gastrointest Pathophysiol 4: 43-46.

Gisbert JP, Calvet X (2011) Review article: common misconceptions in the management of Helicobacter pylori-associated gastric MALT-lymphoma. Aliment Pharmacol Ther 34: 1047-1062.

Hao Q, Li Y, Zhang ZJ, Liu Y, Gao H (2004) New mutation points in $23 \mathrm{~S}$ rRNA gene associated with Helicobacter pylori resistance to clarithromycin in northeast China. World J Gastroenterol 10: 1075-1077.

Hirata K, Suzuki H, Nishizawa T, Tsugawa H, Muraoka H, Saito Y, Matsuzaki J, Hibi T (2010) Contribution of efflux pumps to clarithromycin resistance in Helicobacter pylori. J Gastroenterol Hepatol 25: 75-79.

Ho SL, Tan EL, Sam CK, Goh KL (2010) Clarithromycin resistance and point mutations in the $23 \mathrm{~S}$ rRNA gene in Helicobacter pylori isolates from Malaysia. J Dig Dis 11: 101-105.

den Hollander WJ, Sostres C, Kuipers EJ, Lanas A (2013) Helicobacter pylori and nonmalignant diseases. Helicobacter 18: 24-7.

International Agency for Research on Cancer (IARC) (1994) Monograph on the Evaluation of Carcinogenic Risks to Humans, Vol. 61, Schistosomes, Liver Flukes and Helicobacter pylori. IARC, Lyon, France.

Karczewska E, Klesiewicz K, Skiba I, Wojtas-Bonior I, Sito E, Czajecki K, Zwolińska-Wcisło M, Budak A (2012) Variability in prevalence of Helicobacter pylori strains resistant to clarithromycin and levofloxacin in Southern Poland. Gastroenterol Res Pract 2012: 418010.

Karczewska E, Wojtas I, Budak A (2009) Prevalence of Helicobacter pylori primary resistance to antimicrobial agents in Poland and around the world. Post Mikrobiol 48: 31-41.

Karczewska E, Wojtas-Bonior I, Sito E, Zwolińska-Wcisło M, Budak A (2011) Primary and secondary clarithromycin, metronidazole, 
amoxicillin and levofloxacin resistance to Helicobacter pylori in southern Poland. Pharmacol Rep 63: 799-807.

Konturek PC, Konturek SJ, Brzozowski T (2009) Helicobacter pylori infection in gastric cancerogenesis. J Physiol Pharmacol 60: 3-21.

Malfertheiner P, Megraud F, O'Morain CA, Atherton J, Axon AT, Bazzoli F, Gensini GF, Gisbert JP, Graham DY, Rokkas T, El-Omar EM, Kuipers EJ (2012) European Helicobacter Study Group. Management of Helicobacter pylori infection - the Maastricht IV/ Florence Consensus Report. Gut 61: 646-664.

Mégraud F (2004). Helicobacter pylori antibiotic resistance: prevalence, importance, and advances in testing. Gut 53: 1374-1384.

Mégraud F, Coenen S, Versporten A, Kist M, Lopez-Brea M, Hirschl AM, Andersen LP, Goossens H, Glupczynski Y (2013) Study Group participants. Helicobacter pylori resistance to antibiotics in Europe and its relationship to antibiotic consumption. Gut 62: 34-42.

Mégraud F, Lehours P (2007) Helicobacter pylori detection and antimicrobial susceptibility testing. Clin Microbiol Rev 20: 280-322.

Ménard A, Santos A, Mégraud F, Oleastro M (2002). PCR-restriction fragment length polymorphism can also detect point mutation A2142C in the 23S rRNA gene, associated with Helicobacter pylori resistance to clarithromycin. Antimicrob Agents Chemother 46: 11561157.

Occhialini A, Urdaci M, Doucet-Populaire F, Bébéar CM, Lamouliatte H, Mégraud F (1997) Macrolide resistance in Helicobacter pylori: rapid detection of point mutations and assays of macrolide binding to ribosomes. Antimicrob Agents Chemother 41: 2724-2728.

Oleastro M, Ménard A, Santos A, Lamouliatte H, Monteiro L, Barthélémy P, Mégraud F(2003) Real-time PCR assay for rapid and accurate detection of point mutations conferring resistance to clarithromycin in Helicobacter pylori. J Clin Microbiol 41: 397-402.

Perez-Perez GI, Rothenbacher D, Brenner H (2004) Epidemiology of Helicobacter pylori infection. Helicobacter 9: 1-6.
Raymond J, Burucoa C, Pietrini O, Bergeret M, Decoster A, Wann A, Dupont C, Kalach N (2007) Clarithromycin resistance in Helicobacter pylori strains isolated from French children: prevalence of the different mutations and coexistence of clones harboring two different mutations in the same biopsy. Helicobacter 12: 157-163.

Rimbara E, Noguchi N, Yamaguchi T, Narui K, Kawai T, Sasatsu M (2005) Development of a highly sensitive method for detection of clarithromycin-resistant Helicobacter pylori from human feces. Curr Microbiol 51: $1-5$.

Rożynek E, Dzierżanowska-Fangrat K, Celińska-Cedro D, Jóźwiak P, Madaliński K, Dzierżanowska D (2002) Primary resistance of Helicobacter pylori to antimicrobial agents in Polish Children. Acta Microbiol Pol 51: 255-263.

Schabereiter-Gurtner C, Hirschl AM, Dragosics B, Hufnagl P, Puz S, Kovách Z, Rotter M, Makristathis A (2004) Novel real-time PCR assay for detection of Helicobacter pylori infection and simultaneous clarithromycin susceptibility testing of stool and biopsy specimens. I Clin Microbiol 42: 4512-4518.

Stone GG, Shortridge D, Versalovic J, Beyer J, Flamm RK, Graham DY, Ghoneim AT, Tanaka SK (1997) A PCR-oligonucleotide ligation assay to determine the prevalence of $23 \mathrm{~S}$ rRNA gene mutations in clarithromycin-resistant Helicobacter pylori. Antimicrob Agents Chemother 41: 712-714.

Taylor DE, Ge Z, Purych D, Lo T, Hiratsuka K (1997) Cloning and sequence analysis of two copies of a $23 \mathrm{~S}$ rRNA gene from Helicobacter pylori and association of clarithromycin resistance with $23 \mathrm{~S}$ rRNA mutations. Antimicrob Agents Chemother 41: 2621-2628.

Versalovic J, Osato MS, Spakovsky K, Dore MP, Reddy R, Stone GG, Shortridge D, Flamm RK, Tanaka SK, Graham DY (1997) Point mutations in the $23 \mathrm{~S}$ rRNA gene of Helicobacter pylori associated with different levels of clarithromycin resistance. I Antimicrob Chemother 40: 283-286.. 